Research article

\title{
Molecular identification based on the sequence of internal transcribed spacer (ITS) of the ribosomal nuclear DNA (rDNA) of pathogenic fungus Pythium aphanidermatum (Edson) Fitzp. isolated from soil and its morphology
}

\author{
Maneesha George and Pramod W. Ramteke* \\ Sam Higginbottom University of Agriculture, Technology and Sciences, Post Agricultural Institute, \\ Rewa Road, Naini, Prayagraj-211007, Uttar Pradesh, India \\ *Corresponding Author: pramod.ramteke@shiats.edu.in \\ [Accepted: 25 December 2018]
}

\begin{abstract}
Soil-borne fungi Pythium aphanidermatum causes damping-off of cucumber, coriander and other economically important plants in India and presumably in many other countries. The objective of the present investigation was to characterize the pathogen morphologically in vitro and to confirm its molecular identity by the sequence of ITS region of rDNA. P. aphanidermatum was isolated from soil and cultured in PDB broth and PDA solid media. The characteristic of growth was monitored and the reproductive structures were analyzed. Hyphae were grown with a daily increment of $2.5-3.0 \mathrm{~cm}$ on PDB. Sporangia were swollen, multinucleate and usually measure 10-50 $\mu \mathrm{m}$ in diameter. Oogonia were found mostly terminal, spherical, 22-27 $\mu \mathrm{m}$ in diameter. Fungus was also characterized using molecular methods based on ITS-PCR. The amplified sequence was compared with the available sequences in the NCBI GenBank. The sequence showed $99 \%$ similarity with other species of Pythium. Based on the morphological and molecular characters isolate was confirmed as Pythium aphanidermatum. The isolation, morphological characterization and sequencing of ITS region of rDNA will add knowledge to the scientific community for proper identification and in-depth research on the management of this plant pathogen.
\end{abstract}

Keywords: ITS sequence - Morphological characteristics - Oomycete - Plant pathogen - Pythium aphanidermatum.

[Cite as: George M \& Ramteke PW (2018) Molecular identification based on the sequence of internal transcribed spacer (ITS) of the ribosomal nuclear DNA (rDNA) of pathogenic fungus Pythium aphanidermatum (Edson) Fitzp. isolated from soil and its morphology. Tropical Plant Research 5(3): 385-390]

\section{INTRODUCTION}

The fungus Pythium is a facultative parasite and lives saprophytically on the moist humus in soil and attacks seedlings at the soil level. It causes damping-off, soft-rot, crown-rot, wheat-rot or foot-rot diseases and sometimes causing death (van der Plaats-Niterink 1981, El-Tarabily et al. 2009). One of the species of Pythium, $P$. aphanidermatum (Edson) Fitzp. causes extensive damage to economically important crops worldwide (Martin \& Loper 1999). It causes considerable damage to cucumber crops worldwide by damping-off disease of seedlings and root and Crown-rots of mature plants (Zitter et al. 1996, Chen et al. 2000, Al-Sa'di et al. 2007). It is also a causal pathogen of damping-off disease of coriander in India (Ashwathi et al. 2017). Several studies have also been carried out in India. Muthukumar (2016) isolated twelve different species of Pythium from different soil types, water types, vegetables and ornamental plants of Delhi.

The genus Pythium was first created by Pringsheim in 1858. Taxonomic details of the genus had been described by the end of the $19^{\text {th }}$ century and many new species had been added. Furthermore, the genus was included in a new family, Pythiaceae, by Schroter in 1897 under the kingdom of Stramenopila, subdivision of Mastigomycotina, class of Oomycetes and order of Peronosporales (Domsch et al. 1980). Afterwards, there are almost 307 species of Pythium were morphologically and taxonomically described by different scientist and 
submitted in www.mycobank.org (Middleton 1943, Waterhouse 1968, Plaats-Niterink 1981). An account of this genus in India was given by Butler (1907).

Rapid and safe identification is crucial to implement proper diagnosis and effective treatment to the diseased plants (Schurko et al. 2003). Though the identification and classification of Pythium species are based on morphological and physiological characteristics; but taxonomists faced problems due to a lack of sexual structures and failure to induce in vitro zoosporogenesis (Schurko et al. 2003). Thus the use of molecular technologies has become an indispensable tool for accurate identification of this pathogen (Grooters \& Gee 2002, Schurko et al. 2003, Pannanusorn et al. 2007, Ashwathi et al. 2017). The polymerase chain reaction (PCR) for the amplification of the ribosomal genes are used for the genetic identification of many organisms because they comprise both highly conserved sequences during evolution.

In the present study, we have isolated the fungal pathogen Pythium aphanidermatum. We have identified the pathogen morphologically based on its reproductive structures. We have also obtained the sequence of the internal transcribed spacer (ITS) of the ribosomal nuclear DNA (rDNA) with the PCR method using universal primers (Chen et al. 1992) for the molecular identification and deposited the sequence in Genbank (NCBI).

\section{MATERIALS AND METHODS}

Collection and isolation of the fungus

The Fungus was isolated from Lucknow ( $26^{\circ} 50^{\prime} \mathrm{N}$ latitude, $80^{\circ} 56^{\prime} \mathrm{E}$ longitude, $128 \mathrm{~m}$ above the sea level), the capital of Uttar Pradesh, is spread over an area of $310 \mathrm{Km}^{2}$ in the central plain of the Indian subcontinent. The sample was collected from soil samples together with plant root debris in sterile capped bottles. The fungus was isolated from these samples by the usual baiting techniques (Middleton 1943, Paul et al. 1998). The collected sample was purified in sterile distilled water and maintained on solid media like PDA (potato dextrose agar) at $25^{\circ} \mathrm{C}$ (Booth 1971). The isolate was identified with the help of keys provided by Middleton (1943), Waterhouse (1967), Plaats-Niterink (1981) and also by the sequence obtained from ITS-PCR.

\section{DNA isolation and PCR}

The culture conditions, DNA isolation and the PCR amplification of the ITS of the rDNA were the same as described earlier (Paul et al. 1999, Paul 2000). The fungus was grown in potato dextrose broth medium, incubated at $25^{\circ} \mathrm{C}$ on a rotary shaker for 5 days. The mycelium was then washed in TE buffer $(10 \mathrm{mM} \mathrm{Tris-HCl}$ $\mathrm{pH} 8,1 \mathrm{mM}$ EDTA) and was kept at $320^{\circ} \mathrm{C}$ for $24 \mathrm{~h}$ and DNA was extracted. Polymerase chain reactions were performed in $50 \mu \mathrm{l}$ volumes containing $100 \mathrm{pmol}$ of each of the universal primers ITS1 (TCC GTA GGT GAA CCT GCG G) and ITS4 (TCC TCC GCT TAT TGA TAT GC); $200 \mu \mathrm{M}$ of each of the four dNTPs; $1.5 \mathrm{U}$ of Taq polymerase (Invitrogen) and $300 \mathrm{ng}$ DNA template in a PCR buffer (50 mM KCl, $1.5 \mathrm{mM} \mathrm{MgCl} 2,10 \mathrm{mM}$ Tris-HCl). The temperature cycling parameters were $95^{\circ} \mathrm{C}$ for $3 \mathrm{~min}$ for denaturation the first cycle and $1 \mathrm{~min}$ for subsequent cycles, primer annealing for $1 \mathrm{~min}$ at $55^{\circ} \mathrm{C}$ and primer extension at $72^{\circ} \mathrm{C}$ for 1 min with a total of 35 cycles and a final extension at $72^{\circ} \mathrm{C}$ for $3 \min 25$.

\section{Sequencing and phylogenetic analysis}

The PCR product was purified and sequenced (Chromous Biotech Pvt. Ltd., Bangalore). The sequence was compiled by ApE software (A plasmid Editor). The rDNA sequence was submitted to NCBI gene bank. The sequence was also blasted (NCBI) to determine the percentage of similarity with related sequences. The BioEdit sequence alignment editor was used to obtain multiple alignments of nucleotides with related sequences for ITS. The blast output was processed for generating the phylogenetic tree in software MEGA7 by using 'Maximum Likelihood' method based on the Tamura-Nei model (Tamura \& Nei 1993, Kumar et al. 2016). ITS sequence was aligned with other reported sequence of $P$. aphanidermatum (Genbank accession no. MF040822.1, KY646468.1, MF347709.1) to obtained the percentage of similarity using the online software 'Multalin', which creates a multiple sequence alignment by progressive pairwise alignments (Corpet 1988).

\section{RESULTS AND DISCUSSION}

\section{Morphological descriptions}

Pythium is a representative of class Oomycetes, which bear large spherical Oogonia or female gametangia (Fig. 1) (van der Plaats-Niterink 1981). The class comprises mostly water molds. In the present study, $P$. aphanidermatum was collected from soil and their hyphae were grown with a daily increment of $2.5-3.0 \mathrm{~cm}$ at $25^{\circ} \mathrm{C}$ on PDA. Asexual reproduction occurred under favourable environmental conditions through sporangia which developed into vesicles containing zoospores; which were liberated to give rise to hyphae (Stanghellini \& Burr 1973). Sporangia were swollen, multinucleate and measured 10-50 $\mu \mathrm{m}$ in diameter (Fig. 1). The structure 
of sporangia differs from species to species it can be spherical, filamentous slightly inflated and filamentous inflated. In this study, sporangia were found inflated filamentous, readily produced zoospores on transfer to water at $20-30^{\circ} \mathrm{C}$, which is a typical feature of $P$. aphanidermatum. After maturation, the sporangia get separated from the rest of hyphae by means of a septum as observed here (Fig. 1). When they were matured, a tubular structure called Papilla was developed at the apex or laterally which soon developed into a sac-like thin walled vesicle (Fig. 1). Papilla helps in the dispersal of uninucleate, naked, pyriform, biflagellate zoospores (Stanghellini \& Burr 1973). As Pythium is homothallic, the male and female sex organs were developed in close proximity of each other either on the same or different hypha embedded in the host tissue (Fig. 1). Oogonia were found mostly terminal, spherical, 22-27 $\mu \mathrm{m}$ diameter; oospores aplerotic, 17-19 $\mu \mathrm{m}$ diameter, moderately thickwalled; antheridia were barrel or dome-shaped or cylindrical with a dimension of 11-19 $\mu \mathrm{m}$ long and 10-14 $\mu \mathrm{m}$ wide monoclinous, intercalary or terminal and found 1-2 per oogonium. Ashwathi et al. (2017) observed the similar structure of oogonia (terminal, globose and smooth 20-25 $\mu$ diameter) and antheridia (broadly sacshaped 10-14 $\mu$ long and 10-14 $\mu$ wide, 2 per oogonium) in $P$. aphanidermatum isolated from coriander growing regions of Tamil Nadu, India. Pythium species have been traditionally identified and classified based on the morphology of asexual and sexual structures (Van der Plaats-Niterink 1981) as structures of sporangia and oospore vary between the species (Schroeder et al. 2013). Considering the reproductive structures morphologically the isolated fungus was identified as $P$. aphanidermatum as the similar morphology found in earlier reposts (Ashwathi et al. 2017) and with the help of keys provided by Middleton (1943), Waterhouse (1967), Plaats-Niterink (1981).
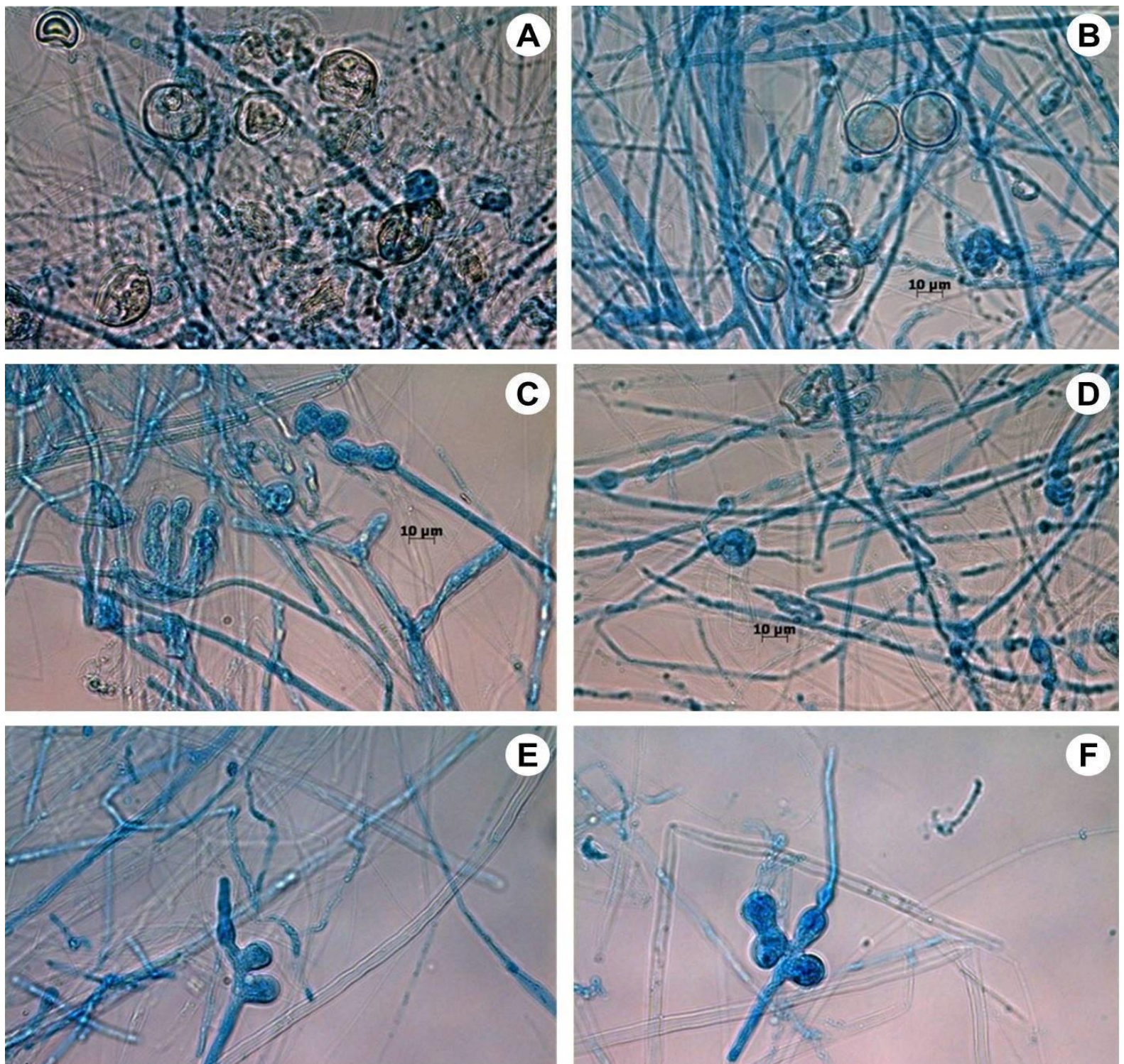

Figure 1. Vegetative and reproductive structures of Pythium aphanidermatum (Edson) Fitzp.: A-B, Oogonia; C-D, Inflated filamentous Sporangia; E, Sporangia with laterally placed Papilla; F, Papilla was developed at the apex of Sporangia.

Molecular identification based on the sequence of ITS region of rDNA

www.tropicalplantresearch.com 
In the present study, the partial ITS sequence of the flanking regions of the rDNA of $P$. aphanidermatum was PCR amplified using the specific forward and reverse primers with an amplicon size 820 base pairs. The sequence was submitted to NCBI GenBank (Accession number MK158217). The sequence of amplified ITS region is given below.
1 tttcgtatcc gattcgcgcc gggtttcgag cgtgtttgta ttcgttactg tgtaatgcag
61 tgatagtgca agcaatgcga ggagctttgg ctgatcgaag gtcgttgcgc aagtatttat
121 atgcgcgctt cggctgactt atactttcaa acccettact ttaaaactg atcaatactg
181 tgaggacgaa agtctttgct ttaaaactag ataacaactt tcagcagtgg atgtctaggc
241 tcgcacatcg atgaagaacg ctgcgaactg cgatacgtaa tgcgaattgc agaattcagt
301 gagtcatcga aattttgaac gcatattgca ctttcgggtt atacctggaa gtatgtctgt
361 atcagtgtcc gtacatcaac cttgcctctc tttgtcggtg tagtccggtt tgtagcatgt
421 gcagatgtga ggtgtctcge ggcgtgtgtg tgtgctgtaa aatgcatacg cttgctgcga
481 gtccetttaa aacgacacga tcttctatt tgctttctat ggagcgcgta tctcgaacgc
541 ggcggtcctc ggatcgetcg cagtcgacag cgacttcagc ggagacatat ggaagaaacc
601 actattcgcg gtacgttagg cttcggetcg acaatgttgc gttttagtgt gtggattccg
$661 \mathrm{tttcgcttt}$ gaggtgtact gttcggttgt gagcttgaac cttgtgtctc gctttgttag
721 tagaggtgtg tcgatttctg tggtttgatt ccgcacttta tgtgtgggta gagagactcc
781 atttgggaaa cattgtactg cgcgtacgct ttcgggtgt

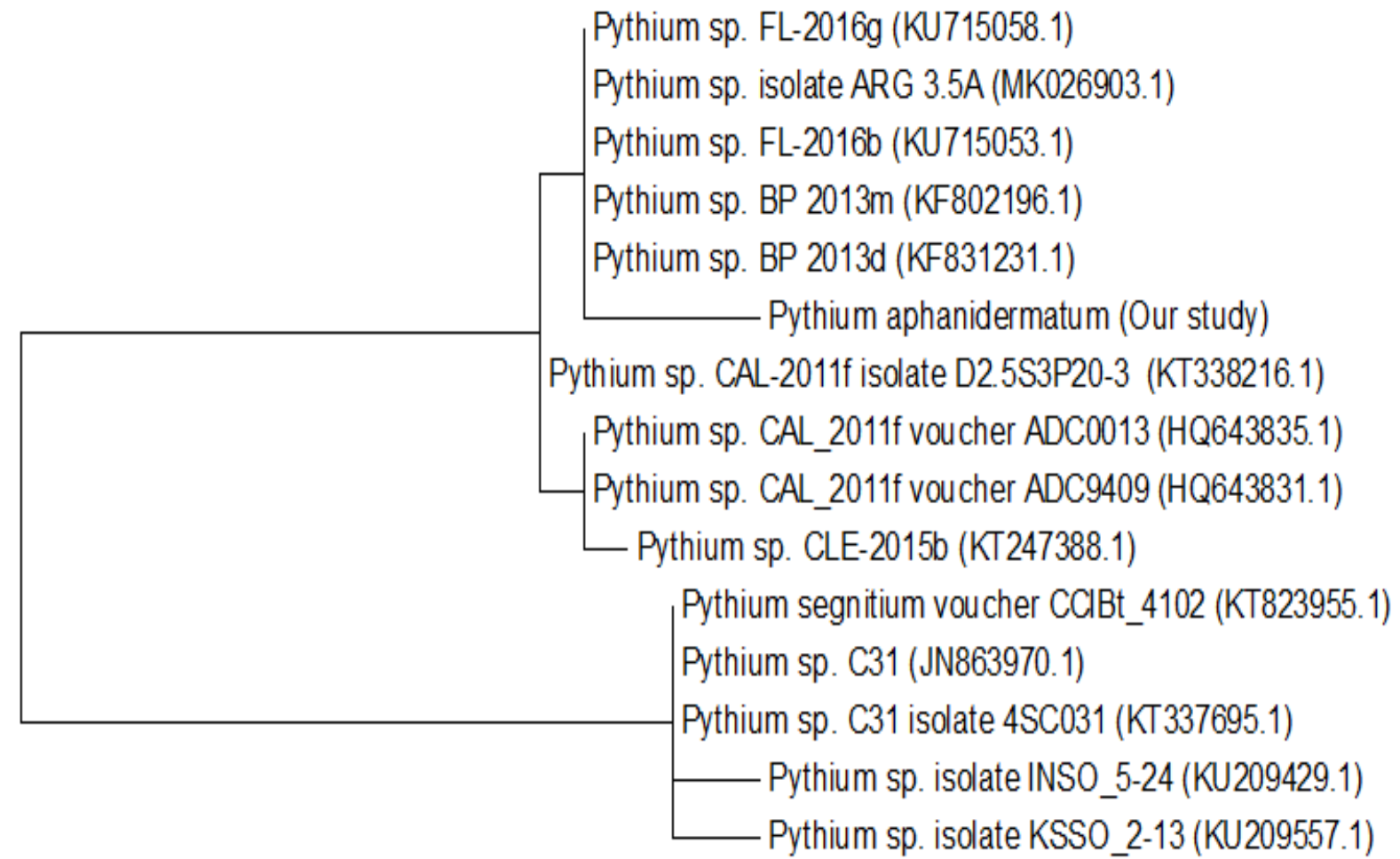

\subsection{0}

Figure 2. Molecular Phylogenetic analysis of Pythium aphanidermatum (Edson) Fitzp. based on the Tamura-Nei model by Maximum Likelihood method. The analysis is based on 14 nucleotide sequences from NCBI BLAST result.

The amplified sequence was blasted in the NCBI. The sequence showed $99 \%$ similarity to partial sequence of ITS-1 of 5.8S ribosomal RNA gene and ITS-2 of large subunit ribosomal RNA gene (MK026903.1, KF831231.1, KF802196.1, KU715058.1 etc.) of different isolates of Pythium sp. (Fig. 2). Phylogenetic analysis based on NCBI Genbank database confirmed the genus as Pythium and morphological observation predicted the species as $P$. aphanidermatum.

The ITS sequence was aligned with other reported sequence of $P$. aphanidermatum (Genbank accession no. MF040822.1, KY646468.1, MF347709.1) and found maximum 90\% of similarity (Fig. 3). 


\begin{tabular}{|c|c|c|c|c|c|c|c|c|c|c|c|c|c|c|}
\hline & 1 & 10 & 20 & 30 & 40 & 50 & 60 & 70 & 80 & 90 & 100 & 110 & 120 & 130 \\
\hline \multirow[t]{2}{*}{$\begin{array}{l}\text { 1_ITSF_Pythiun } \\
\text { MF040822.1 } \\
\text { KY646468.1 } \\
\text { MF347709.1 } \\
\text { Consensus }\end{array}$} & \multicolumn{14}{|c|}{ 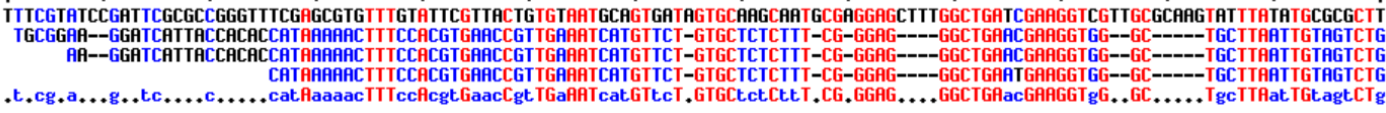 } \\
\hline & & 140 & 150 & 160 & 170 & 180 & 190 & 200 & 210 & 220 & 230 & 240 & 250 & 260 \\
\hline \multirow[t]{2}{*}{$\begin{array}{l}\text { 1_ITSF_Pythiun } \\
\text { MF040822.1 } \\
\text { KY646468.1 } \\
\text { MF347709.1 } \\
\text { Consensus }\end{array}$} & \multicolumn{14}{|c|}{ 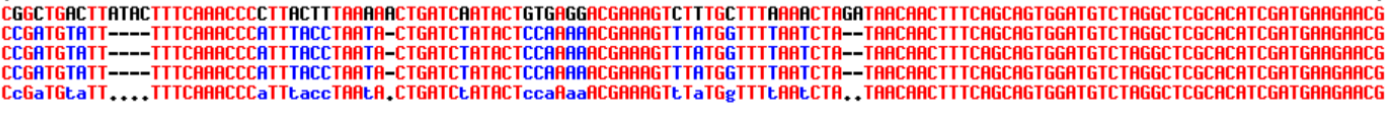 } \\
\hline & 261 & 270 & 280 & 290 & 300 & 310 & 320 & 330 & 340 & 350 & 360 & 370 & 380 & 390 \\
\hline \multirow[t]{2}{*}{$\begin{array}{l}\text { 1_ITSF_Pythiun } \\
\text { MF040822.1 } \\
\text { KY646468.1 } \\
\text { MF347709.1 } \\
\text { Consensus }\end{array}$} & \multicolumn{14}{|c|}{ 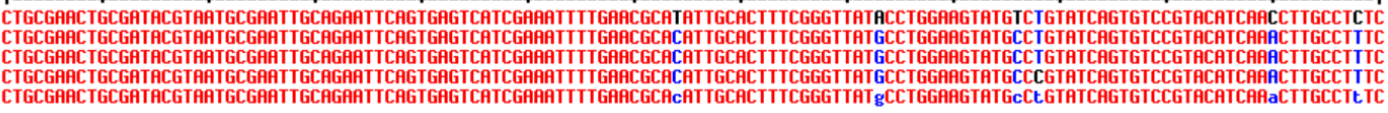 } \\
\hline & 391 & 400 & 410 & 420 & 430 & 440 & 450 & 460 & 470 & 480 & 490 & 500 & 510 & 520 \\
\hline \multirow[t]{2}{*}{$\begin{array}{r}\text { 1_IISF_Pythiun } \\
\text { MF040822.1 } \\
\text { KY646468.1 } \\
\text { MF347709.1 } \\
\text { Consensus }\end{array}$} & \multicolumn{14}{|c|}{ 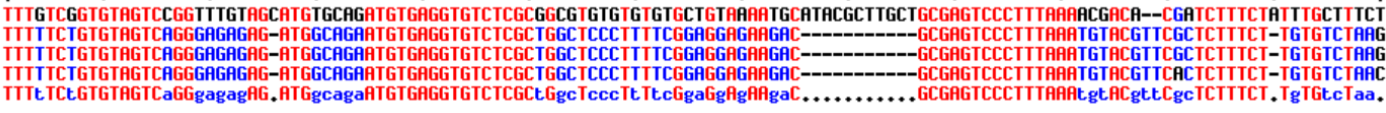 } \\
\hline & $5<1$ & 530 & 540 & 550 & 560 & 570 & 580 & 590 & 600 & 610 & 620 & 630 & 640 & 650 \\
\hline \multirow[t]{2}{*}{$\begin{array}{l}\text { 1_ITSF_Pythiun } \\
\text { MF040822.1 } \\
\text { KY646468.1 } \\
\text { MF347709.1 } \\
\text { Consensus }\end{array}$} & \multicolumn{14}{|c|}{ 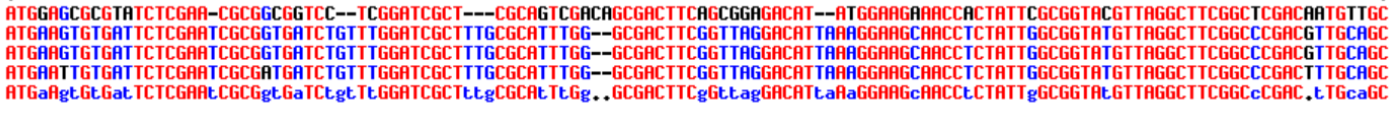 } \\
\hline & 651 & 660 & 670 & 680 & 690 & 700 & 710 & 720 & 730 & 740 & 750 & & 770 & \\
\hline
\end{tabular}

Figure 3. Multiple sequence alignment of the ITS sequence of Pythium aphanidermatum (Edson) Fitzp. with previously reported different isolates of Pythium aphanidermatum (Genbank accession no. MF040822.1, KY646468.1, MF347709.1).

The small difference in the ITS region is significant for the genus Pythium. The results of the sequence alignment support the morphological observations as found in earlier reports (Grooters \& Gee 2002, Schurko et al. 2003, Pannanusorn et al. 2007, Ashwathi et al. 2017).

\section{CONCLUSION}

Pathogenic fungus Pythium aphanidermatum was isolated from Lucknow, India. The taxonomic identification was carried out by morphological diagnosis and molecular analysis. After the analysis of the characteristics and dimensions of hyphae, sporangia and sexual reproductive structures, this fungal pathogen was identified as Pythium aphanidermatum. The partial ITS sequence of the rDNA of P. aphanidermatum was obtained and submitted to NCBI GenBank (Accession number MK158217). Phylogenetic analysis revealed its similarity with other Pythium species. The isolation and identification of this fungus will help in further research on accurate biological control for this plant pathogen.

\section{ACKNOWLEDGEMENTS}

Authors are grateful to Sam Higginbottom University of Agriculture, Technology and Sciences, Post Agricultural Institute of Prayagraj, Uttar Pradesh for throughout support to carry out the work.

\section{REFERENCES}

Al-Sa'di AM, Drenth A, Deadman ML, De Cock AW \& Aitken EA (2007) Molecular characterization and pathogenicity of Pythium species associated with damping-off in greenhouse cucumber (Cucumis sativus) in Oman. Plant Pathology 56: 140-149.

Ashwathi S, Ushamalini C, Parthasarathy S \& Nakkeeran S (2017) Morphological, pathogenic and molecular characterisation of Pythium aphanidermatum: A causal pathogen of coriander damping-off in India. The Pharma Innovation 6: 44.

Booth C (1971) Fungal Culture Media. In: Methods in microbiology. Academic Press, Elsevier, United States, Vol. 4, Chapter II, pp. 49-94.

Butler EJ (1907) An account of the genus Pythium and some Chytridiaceae. Memoirs of the Department of Agriculture in India (Botanical series) 1: 1-160.

Chen C, Belanger RR, Benhamou N \& Paulitz TC (2000) Defense enzymes induced in cucumber roots by treatment with plant growth-promoting rhizobacteria (PGPR) and Pythium aphanidermatum. Physiological and Molecular Plant Pathology 56: 13-23.

Chen W, Schneider RW \& Hoy JW (1992) Taxonomic and phylogenetic analyses of ten Pythium species using isozyme polymorphisms. Phytopathology 82: 1234-1244.

Corpet F (1988) Multiple sequence alignment with hierarchical clustering. Nucleic Acids Research 16: 1088110890. 
Domsch KH, Gams W \& Anderson TH (1980) Pythium Pringsheim 1858. Compendium of soil fungi. Academic Press, Elsevier, New York, United States, pp. 678-697.

El-Tarabily KA, Nassar AH, Hardy GS \& Sivasithamparam K (2009) Plant growth promotion and biological control of Pythium aphanidermatum, a pathogen of cucumber, by endophytic actinomycetes. Journal of Applied Microbiology 106: 13-26.

Grooters AM \& Gee MK (2002) Development of a nested polymerase chain reaction assay for the detection and identification of Pythium insidiosum. Journal of Veterinary Internal Medicine 16: 147-152.

Kumar S, Stecher G \& Tamura K (2016) MEGA7: Molecular Evolutionary Genetics Analysis version 7.0 for bigger datasets. Molecular Biology and Evolution 33: 1870-1874.

Martin F \& Loper JE (1999) Soilborne diseases caused by Pythium species ecology, epidemiology and prospects for biological control. Critical Reviews in Plant Sciences 18: 111-181.

Middleton JT (1943) The taxonomy, host range and geographic distribution of the genus Pythium. Memoirs of the Torrey Botanical Club 20: 1-171.

Muthukumar A, Udhayakumar R \& Naveenkumar R (2016) Ecofriendly management of damping-off of solanaceous crops caused by Pythium species. In: Current Trends in Plant Disease Diagnostics and Management Practices. Springer, United States, pp. 49-90.

Pannanusorn S, Chaiprasert A, Prariyachatigul C, Krajaejun T, Vanittanakom N, Chindamporn A, Wanachiwanawin W \& Satapatayavong B (2007) Random amplified polymorphic DNA typing and phylogeny of Pythium insidiosum clinical isolates in Thailand. Southeast Asian Journal of Tropical Medicine and Public 38: 383.

Paul B (2000) ITS1 region of the rRNA of Pythium megacarpum sp. nov., its taxonomy, and its comparison with related species. FEMS Microbiology Letters 183: 105-110.

Paul B, Galland D \& Masih I (1999) Pythium prolatum, isolated from soil in the Burgundy region: a new record for Europe. FEMS Microbiology Letters 173: 69-75.

Paul B, Galland D, Bhatnagar T \& Dulieu H (1998) A new species of Pythium isolated from the Burgundy region of France. FEMS Microbiology Letters 158: 207-213.

Plaats-Niterink AJ (1981) Monograph of the genus Pythium. Studies in Mycology 21: 1-242.

Pringsheim N (1858) Contribution to morphology and systematics of algae. 2, The Saprolegniales. Jb Wiss Botany 1: 284-306.

Schroeder KL, Martin FN, de Cock AWAM, Lévesque CA, Spies CFJ, Okubara PA \& Paulitz TC (2013) Molecular detection and quantification of Pythium species: evolving taxonomy, new tools, and challenges. Plant Disease 97: 4-20.

Schroter J (1897) Pythiaceae. Engler \& Prantl nat PflFam 11: 104-105.

Schurko AM, Mendoza L, Lévesque CA, Désaulniers NL, De Cock AW \& Klassen GR (2003) A molecular phylogeny of Pythium insidiosum. Mycological Research 107(5): 537-544.

Stanghellini ME \& Burr TJ (1973) Germination in vivo of Pythium aphanidermatum oospores and sporangia. Phytopathol 63: 1493-1496.

Tamura K \& Nei M (1993) Estimation of the number of nucleotide substitutions in the control region of mitochondrial DNA in humans and chimpanzees. Molecular Biology and Evolution 10: 512-526.

van der Plaats-Niterink AJ (1981) Monograph of the genus Pythium. Baarn: Centraalbureau voor Schimmelcultures, Studies in mycology, Vol. 21, pp. 1-242.

Waterhouse GM (1967) Key to Pythium Pringsheim. Mycology Papers 109: 1-15.

Zitter TA, Hopkins DL \& Thomas CE (1996) Compendium of Cucurbit Diseases. American Phytopathological Society Press, St Paul MN. 